\title{
Inhaled nitric oxide and high concentrations of oxygen in pediatrics patients with congenital cardiopathy and pulmonary hypertension: Report of five cases
}

\author{
Departments of Pediatrics and Cardiology, Escola Paulista de Medicina, \\ Universidade Federal de São Paulo - São Paulo, Brazil
}

Five patients with ages ranging from 6 months to 3 years were analyzed. All received inhaled nitric oxide (NO - 20 parts per million $(\mathrm{ppm}))$ and oxygen $\left(\mathrm{O}_{2}\right.$ - at a concentration of $\left.90-95 \%\right)$ by means of an oxygen hood. Mean Pulmonary Artery Pressure (MPAP), Mean Aortic Pressure (MAoP), Pulmonary Vascular Resistance (PVR) and Systemic Vascular Resistance (SVR) were measured and the calculation of their relationship to pulmonary/systemic flow (Qp/Qs) was performed by the catheterization of the femoral artery vein. Three patients presented reduction in PVR and increase in Qp/Qs. There were no systemic alterations or any side effect from using NO.

UNITERMS: Nitric Oxide - Pulmonary Hypertension- Congenital Cardiopathy.

\section{INTRODUCTION}

$\mathrm{P}$ ulmonary hypertension $(\mathrm{PH})$ is associated with high mortality rate in several pathologies such as neonatal persistent pulmonary hypertension, acute respiratory discomfort syndrome, in patients with chronic obstructive pulmonary disease, and especially in the immediate postoperative period after surgical correction of congenital cardiopathies which are accompanied by
$\mathrm{PH}{ }^{(1)}$. Pulmonary hypertension contributes to the worsening of hypoxemia and overload of the right ventricle. These cardiopathies lead to hypertrophy and hyperplasia of the vascular musculature and consequent vasoconstriction. Conventional treatment after surgery consists of using hyperventilation, alkalization, increase in the inhaled oxygen fraction, inotropics and vasodilators.

The great advantage in using inhaled nitric oxide (NO) is that, contrary to systemic vasodilators, it only reaches the ventilated alveoli, thereby causing selective pulmonary vasodilation ${ }^{(2,3)}$ with deviation of the flow to these areas, thus improving oxygenation and intrapulmonary shunt, in a manner similar to what occurs with the use of high oxygen concentrations in the evaluation prior to surgery, during catheterization. 
Our main objective was to verify whether inhaled NO is a safe procedure for patients with congenital cardiopathies and for the professional group involved in its application. As a secondary objective, we compared inhaled NO with the administration of oxygen concentrations close to $100 \%$, observing alterations in the mean pulmonary artery pressure (MPAP), mean aortic pressure (MAoP), pulmonary vascular resistance (PVR), systemic vascular resistance (SVR) and the relationship of pulmonary/systemic flow (Qp/Qs) during the preoperative phase, for pediatric patients with congenital cardiopathy and $\mathrm{PH}$.

\section{PATIENTS AND METHODS}

This study was carried out with the approval of the Medical Ethics Committee of the São Paulo Hospital. Criteria for participation in this study were children below 13 years with congenital cardiopathy and who presented pulmonary hypertension with MPAP $>25 \mathrm{mmHg}$, before surgical correction. The sample consisted of 5 patients presenting several types of cardiopathies and ages ranging from 6 months to 3 years, as shown in Table 1. All patients presented pulmonary hypertension by intracardiac shunt.

The children were submitted to catheterization through cannulation of the femoral artery. Hemodynamic measurements of the aortic pressure $(\mathrm{mmHg})$, pulmonary artery $(\mathrm{mmHg})$ and right atrium $(\mathrm{mmHg})$, and measurements of pulmonary and systemic vascular resistances (Wood units), and pulmonary (Qp) and systemic (Qs) flows, were obtained by a standard formula, where the flow is the ratio between the oxygen consumption and the difference in the arterial and venous oxygen content $\left(\mathrm{Q}=\mathrm{VO}_{2} / \mathrm{CaO}_{2}-\mathrm{CvO}_{2}\right.$, where $\mathrm{VO}_{2}=$ oxygen consumption; $\mathrm{CaO}_{2}=$ arterial oxygen content; $\mathrm{CvO}_{2}=$ Venous oxygen content). These measurements were obtained in three phases: basal, with 10 minutes of oxygen inhalation, and 5 minutes of NO inhalation at a concentration of 20 parts per million (ppm).

During the procedure, the patients were sedated with midazolam, intravenous (IV) at a dosage of $0.1 \mathrm{mg} / \mathrm{kg}$, and breathed room air spontaneously. For inhalation, an oxygen hood with a $15 \mathrm{~L} / \mathrm{min}$ oxygen flow reaching concentrations between $90 \%$ to $95 \%$ was used for 10 minutes. NO was applied using a cylinder with a mixture of nitric oxide and nitrogen $\left(\mathrm{NO} / \mathrm{N}_{2}\right)$ of $1000 \mathrm{ppm}$. The gas entered the circuit and mixed with oxygen at a flow of $51 / \mathrm{min}$ just before the entrance of the hood (Fig. 1).

\section{Table I}

Diagnosis of cardiopathies and age range of 5 patients submitted to inhaled NO and oxygen at high concentrations.

\begin{tabular}{|c|c|c|}
\hline Case & Age & Cardiopathy \\
\hline 1 & 2 years & $\begin{array}{l}\text { Interventricular communication, } \\
\text { Aortic insufficiency. }\end{array}$ \\
\hline 2 & 2 years & Ostio atrium-ventricularis comunis \\
\hline 3 & 1 year & Interventricular communication \\
\hline 4 & 3 years & $\begin{array}{l}\text { Interventricular communication, } \\
\text { Persistence of the arterial canal }\end{array}$ \\
\hline 5 & 6 months & $\begin{array}{l}\text { Interventricular and interatrial } \\
\text { communication }\end{array}$ \\
\hline
\end{tabular}

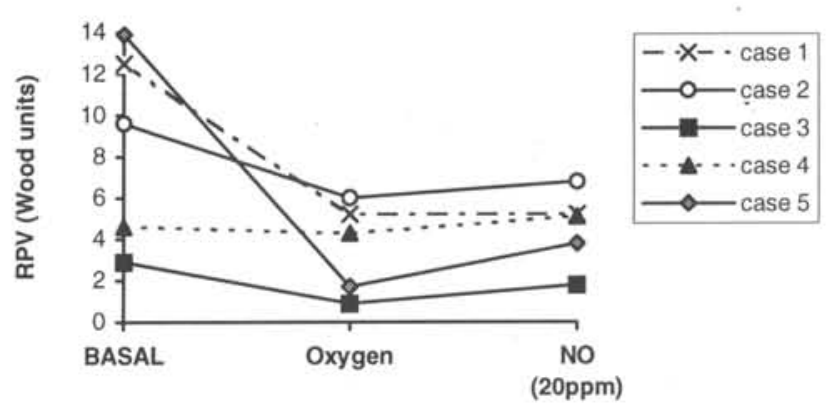

Figure 1 - Alterations in pulmonary vascular resistance (PVR) during inhalation of $\mathrm{NO}(20 \mathrm{ppm})$ and oxygen at high concentrations.

During NO inhalation, the inhaled oxygen fraction was maintained at a level of $40 \%$ to $50 \%$. Monitoring of NO and nitrogen dioxide $\left(\mathrm{NO}_{2}\right)$ was performed with a Bedfont EC90 monitor (Bedfont Scientific Ltd); monitoring of the inhaled fraction of oxygen was performed through a MiniOX III monitor (Catalyst Research), placed close to the patient's nostril.

\section{RESULTS}

In this study we could observe, as shown in Figure 1, that patients 1,2 and 5 presented a decrease in pulmonary vascular resistance using $\mathrm{NO}$ at $20 \mathrm{ppm}$ similar to the result 


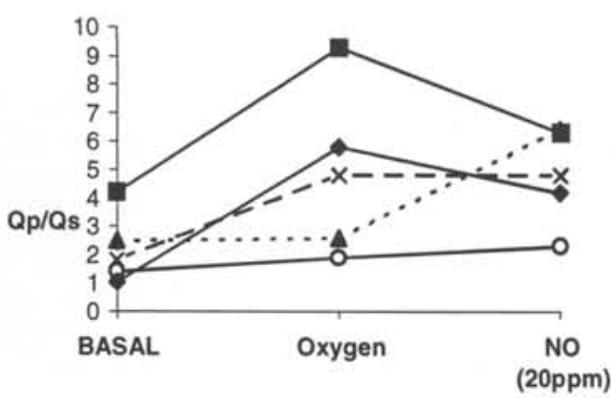

Figure 2 - Alterations in the relationship pulmonary/systemic flow $(\mathrm{Qp} / \mathrm{Qs})$ during inhalation of $\mathrm{NO}(20 \mathrm{ppm})$ and oxygen at high concentrations.

obtained with oxygen inhaled in high concentrations. An increase in the relationship of pulmonary to systemic flow (Qp/Qs) was observed in two patients with $\mathrm{O}_{2}$ and only one with $\mathrm{NO}$, as shown in Figure 2.

Regarding systemic alterations, there was no fall in vascular resistance or in aortic pressure when using NO (Figure 3).

The concentration of nitrogen dioxide $\left(\mathrm{NO}_{2}\right)$ varied from 0 to $0.4 \mathrm{ppm}$ in the interior of the oxygen hood while in the procedure room (total area $12 \mathrm{~m}^{2}$ ) the concentration of $\mathrm{NO}$ varied from 0 to $5 \mathrm{ppm}$ and $\mathrm{NO}_{2}$ was not detectable.

In addition, we did not observe any symptomatology in the professional workers (headache or vomit) related to the inhaled NO.

\section{DISCUSSION}

There are now several studies ${ }^{(4.5)}$ which have demonstrated that the clinical use of inhaled NO is a safe procedure as long as some precautions are taken: training of the professional group responsible for utilization of the gas, and constant monitoring of $\mathrm{NO} / \mathrm{NO}_{2}$ concentrations as well as the levels of metahemoglobinemia. According to the Institute of Occupational Security and Administration of Health of the United States ${ }^{(6)}$, the limit fixed for exposure to NO is $25 \mathrm{ppm}$, when inhaled for 8 hours/day, and that of $\mathrm{NO}_{2}$ is $5 \mathrm{ppm}$. In this study, the formation of $\mathrm{NO}_{2}$ in the interior of the oxygen hood did not surpass $0.4 \mathrm{ppm}$, it was not detectable in the procedure room, and the concentration of NO in the room did not exceed $5 \mathrm{ppm}$; all these values are considered highly acceptable.

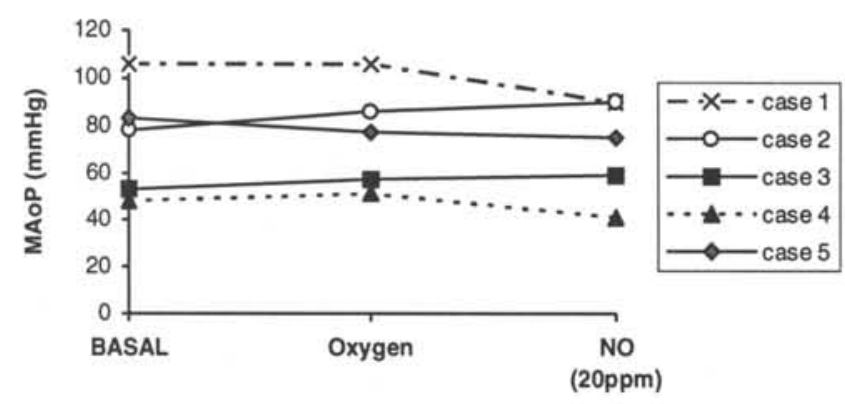

Figure 3 - Alterations in the mean aortic pressure (PAoP) during inhalation of oxygen at high concentrations and $\mathrm{NO}(20$ ppm).

In our experiment NO proved to be an easy-to-use substance and we did not observe any immediate complication or any side-effect during the procedure. None of the professional workers presented any symptomatology (headache or vomit).

Data in the literature ${ }^{(7.89)}$ have demonstrated the role of inhaled NO for decreasing PVR and improving the oxygenation of patients in the pre- and postoperative periods of pediatric surgical correction. Roberts et al..$^{(5)}$ observed a significant reduction in pulmonary vascular resistance, using inhaled NO during catheterization or preoperative evaluation in children with congenital heart diseases and $\mathrm{PH}$; and he did not observe systemic hypotension or significant increases in the levels of metahemoglobinemia.

Although in our initial experience with on small sample of 5 patients, no statistically significant differences were observed regarding the fall of PVR when using inhaled NO as compared to basal data, we observed that three of these patients had a significant fall in PVR and an increase in the relationship Qp/Qs, similar to that obtained by using oxygen in high concentrations ( 90 to $95 \%$ ). These results indicate that NO at $20 \mathrm{ppm}$ was able to provoke dilation of the pulmonary vascular smooth musculature without causing significant systemic changes, since we observed that the values of SVR remained unaltered and very close to those measured during the basal phase, in accordance with what has been reported in many clinical studies ${ }^{(4,5)}$. Oxygen at high concentrations may become a highly toxic gas leading to severe pulmonary disturbances such as atelectasis, mucous dryness and especially cytotoxic lesions with pulmonary edema and respiratory insufficiency ${ }^{(10)}$. 


\section{Resumo}

Cinco pacientes com cardiopatia congênita e hipertensão pulmonar receberam o oxido nítrico (NO - 20 partes por milhäo $(\mathrm{ppm})$ ) inalatório e o oxigênio $\left(\mathrm{O}_{2}\right)$ na concentração de $\left.90-95 \%\right)$ ) por meio de uma tenda de oxigênio. Através do cateterismo da artéria e veia femural foram mensuradas as pressāo média de artéria pulmonar (PmAP), pressão média de aorta (PmAo), resistência vascular pulmonar (RVP), resistência vascular sistêmica (RVS) e feito o cálculo da relação fluxo pulmonar/sistêmico ( Qp/Qs). Três pacientes apresentaram uma redução na RVP e um aumento no Qp/Qs. Não foram observadas alteraçōes sistêmicas ou qualquer efeito colateral com a utilização do NO.

\section{REFERENCES}

1. Hopkins R, Bull C, Haworth S et al. Pulmonary hypertensive crises following surgery for congenital heart defects in young children. Eur J Cardiothorac Surg 1991; 5: 628-34.

2. Pepke-Zaba J, Higenbottam TW, Dinh-Xuan A et al. Inhaled nitric oxide as a cause of selective pulmonary vasodilatation in pulmonary hypertension. Lancet 1991; 338:1173-74.

3. Schranz D, Huth R, Wippermann F et al. Nitric oxide and prostacyclin lower suprasystemic pulmonary hypertension after cardiopulmonary bypass. Eur J Pediatr 1993;152: 793-96.

4. Frostell C, Blomqvist $\mathrm{H}$, Zapol W. Inhaled nitric oxide selectively reverses human hypoxic pulmonary vasoconstriction without causing systemic vasodilatation. Anesthesiology 1993; 78: 427-35.
5. Roberts Jr JD, Lang P, Bigatello ML et al. Inhaled nitric oxide in congenital heart disease. Circulation 1993; 87 (2): 447-53.

6. Niosh. Recommendations for occupational Safety and Health standards. MMWR Morb Mortal Wkly Rep 1988; 37(suppl 7):1-29.

7. Finner NN, Etches PC, Kamstra B et al. Inhaled nitric oxide in infants referred for extracorporeal membrane oxygenation: dose response. J Pediatr 1994;124: 302-8.

8. Journois D, Pouard P, Mauriat P et al. Inhaled nitric oxide as a therapy for pulmonary hypertension after operations for congenital heart defects. J Thorac Cardiovasc Surg 1994; 107(4):1129-35.

9. Miller OJ, Celemajer DS, Deanfield JE et al. Very low dose inhaled nitric oxide: a selective pulmonary vasodilator after operations for congenital heart disease. J. Thorac Cardiovasc Surg 1994;108:487-94.

10. Meneghini R. A toxicidade do oxigênio. Ciência Hoje 1987; 5:57-52. 